INTERDISCIPLINARIA ARCHAEOLOGICA NATURAL SCIENCES IN ARCHAEOLOGY

\title{
Musings on Early Farming Communities in Northwest Anatolia; and other Flights of Fancy
}

\author{
Malcolm Lillie ${ }^{\mathrm{a}^{*}}$, Chelsea Budd ${ }^{\mathrm{b}}$, Songül Alpaslan-Roodenberg ${ }^{\mathrm{c}}, \mathrm{Necmi}_{\text {Karul }}^{\mathrm{d}}$, Ron Pinhasi \\ ${ }^{a}$ Department of Geography, Environment and Earth Sciences, University of Hull, Hull, HU6 7RX, United Kingdom \\ ${ }^{b}$ Research Laboratory for Archaeology \& the History of Art, University of Oxford, Dyson Perrins Building, South Parks Road, Oxford, OX1 3QY, United Kingdom \\ 'Independent palaeo- and physical anthropologist, Leiden, Netherlands \\ ${ }^{d}$ Department of Prehistory, Istanbul University, 34134 Laleli - Istanbul, Turkey \\ ${ }^{e}$ Department of Archaeology, University College Cork, Cork, Ireland
}

\section{ARTICLE INFO}

\section{Article history:}

Received: 15 May 2012

Accepted: 29 August 2012

\section{Key words:}

Anatolia

farming subsistence

stable isotope analysis

$\delta^{13} \mathrm{C}$ and $\delta^{15} \mathrm{~N}$

prehistoric cemeteries and sites

human bones

faunal remains

\begin{abstract}
A B S TRACT
In the tradition of searching for the subtle details that are pertinent to the origins and development of agriculture, to seeking an understanding of the nature of the transition and to the characterisation of early farming communities, this paper will offer some thoughts on the northwestern part of Anatolia in the area to the south of the Sea of Marmara, with a focus on on-going research at the site of Aktopraklik (Figure 1). Following Marek Zvelebil's increasing desire to adopt a multi-disciplinary approach to the archaeological record of the first farmers, the authors of this paper represent colleagues who specialise in a range of techniques including palaeopathology, stable isotopes analysis and archaeology.

We endeavour here to offer some insights into early farming populations in this region on the basis of recent research and excavations, and the analysis of skeletal remains from the site of Aktopraklik in northwestern Anatolia. In approaching the dataset from the perspective of the individual as a window into the population, it is anticipated that important insights into past human subsistence, settlement and social interactions during the earlier stages of the transition from an emphasis on the exploitation of biologically "wild", to biologically "domesticated" resources will be forthcoming (Zvelebil, Lillie 2000, 58).
\end{abstract}

\section{Introduction}

This paper represents the first stage of a newly developing research agenda that is being embarked upon with colleagues working in northwestern Anatolia. After many long discussions with Marek, some in the Café de Paris in Prague in 2010, and others closer to home in Hull and Sheffield in the weeks and months immediately prior to Marek's passing, the first author was beginning to consider the ways in which his own work could be applied more widely to areas in Eastern and Southeastern Europe, particularly through the application of AMS dating, palaeoanthropological and stable isotopic analysis of prehistoric human dietary pathways. After researching in Eastern Europe since 1993, the first author still finds it disquieting to think that limitations,

${ }^{*}$ Corresponding author. E-mail: m.c.lillie@hull.ac.uk in terms of cooperation, access to resources, intellectual discourse, and political, theoretical and methodological issues (amongst others) still inhibit wide reaching interdisciplinary collaborative partnerships throughout Europe. With this in mind, the current research began after discussions with Ron Pinhasi who had just received European Research Council funding for a wide reaching project entitled "Charting the population history of anatomically modern Europeans from their first arrival until the advent of farming".

The area discussed in the current paper (Figure 1) was chosen because there is, in general, something of a regional "gap" in our understanding of the transmission of agriculture from the Levant into southeastern Europe, due, in no small part, to the fact that research undertaken in northwestern Anatolia was not viewed as being "central" to an understanding of Neolithisation in Europe per se. This region is effectively a "blank area" on many maps showing colonisation routes into Europe, with these colonists often 


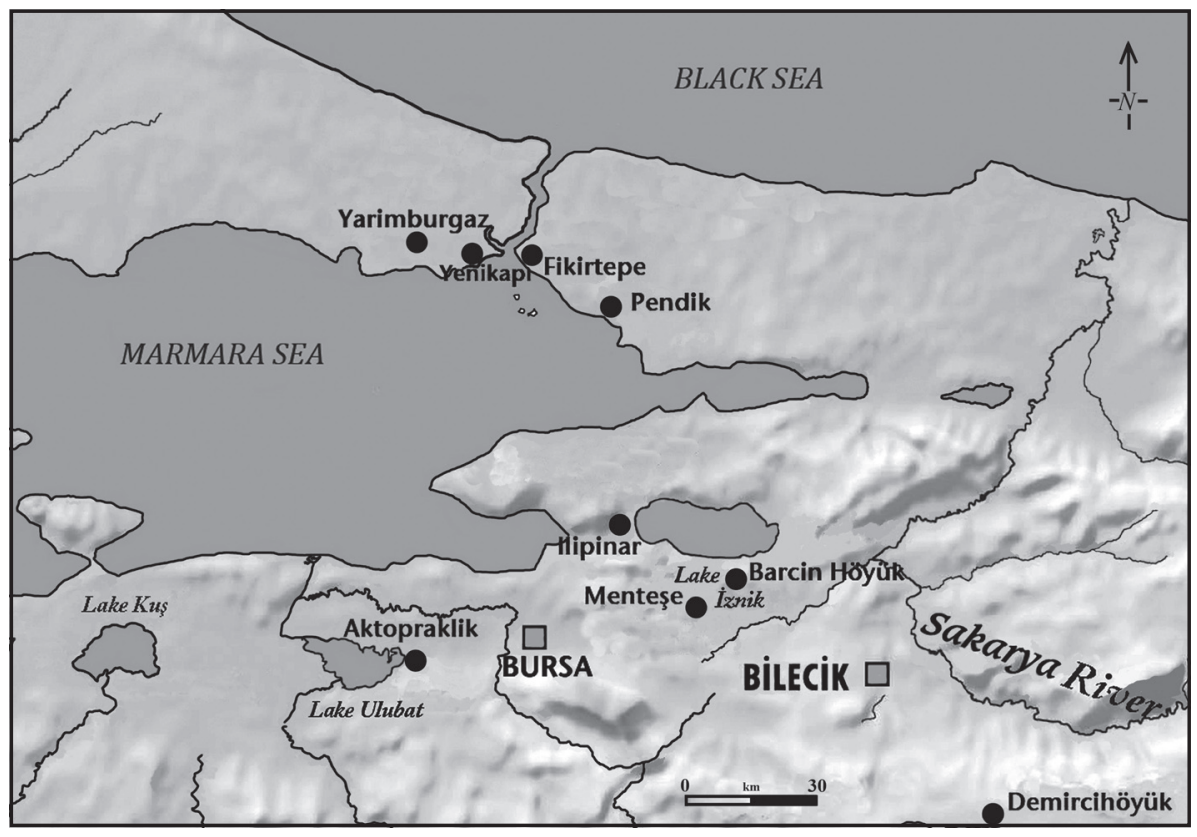

Figure 1. Location of key sites mentioned in the text.

being seen as taking a route directly west from the Anatolian plateau out across the Aegean Sea, to colonise Greece and the southern Balkans (Figure 2; Tringham 2000). As noted by Özdoğan $(2011,415)$ "the problem has been unresolved because of the lack of research in the peripheral areas of primary Neolithization and in particular in the contact zone between Anatolia and southeastern Europe". In effect, the integration of central and western Anatolia into the debate has only effectively come about in the past decade or so (Özdoğan 2011), and northwestern Anatolia is still in need of further resolution. Recently, Perles et al. $(2011,42)$ have stated that "the increasing number of archaeological excavations and surveys of Neolithic settlements in western Turkey have started to fill up what was, until a few years ago, almost an archaeological void for the Neolithic"; the current paper is aimed at adding further resolution to the regional dataset.

The situation is in fact being addressed to some significant degree, and research has been, or is being undertaken at a number of Neolithic farming sites in and around the Marmara region. In fact, excavations have been occurring since the 1950s (e.g. at Fikirtepe), onwards (e.g. at Pendik, Yarımburgaz, Ilıpınar, Menteşe and Barcın - on-going excavations), and more recently at sites such as Aktoprakl1k. The available evidence indicates that a fully developed farming economy occurs from $\mathrm{ca} .6500 \mathrm{cal} \mathrm{BC}$ at the sites of Menteşe and Barcin. Importantly in this context, the recent dating of the phases of activity at Aktoprakl1k indicates that this settlement was occupied from the mid $7^{\text {th }}$ to mid $6^{\text {th }}$ millennia BC, between $c a .6400-5635$ cal BC, and this activity includes the earliest evidence for Neolithic monochrome pottery in the region. These dates place Aktopraklik firmly within the Neolithic to Chalcolithic periods, and as such an overview of the nature of palaeopathology and diet at this site should provide an important basis for future investigations in this region.

There are two preliminary AMS dates for the interments at Aktoprakliik (Table 1), with a Neolithic interment (individual 89D-4.4-06) placed at 6400-6235 cal BC (OxA20596), and an early Chalcolithic burial (individual 88E-12.1-07) placed at 5736-5635 cal BC (OxA-20597) (both at 2 $\sigma$ ). Further dating will be undertaken by one of us (Budd) as an integral part of on-going $\mathrm{PhD}$ research, but it is important to note that these dates, and the dates obtained for Menteşe and Barcin fully overlap with the earlier dates for the Neolithic and Eneolithic of southeastern Europe during the phase of Neolithization; from ca. 6500-3500 cal BC (Tringham 2000, 21 , Perlès 2003, 2005). As such, given the nature of the evidence, the lack of consideration from western scholars in relation to the position that northwestern regions of Anatolia played in relation to the dissemination of agriculture from the Levant, is perhaps perplexing to say the least.

The current discussion is therefore aimed at moving away from the generalised, macroscopic approaches that have been used to study the transition to farming in south-eastern Europe (sensu Tringham 2000, 23), towards a more nuanced "micro-scale" level of analysis aimed at providing greater insights into the complexities of these changes, whether in terms of subsistence, technology or settlement patterning, in

Table 1. Radiocarbon ages and associated anthropological/stable isotope data for two individuals from the Aktopraklık settlement and cemetery site.

\begin{tabular}{|c|c|c|c|c|c|c|c|c|c|}
\hline Burial Code & Sex & Age & Period & Laboratory Code & Date & SD & $\delta^{13} \mathrm{C}$ & $\delta^{15} \mathbf{N}$ & $\mathrm{C}: \mathbf{N}$ \\
\hline 89D-4.4-06 & M? & Young Adult & L. Neolithic & OxA-20596 & 7444 & 37 & -19.05 & 9.46 & 3.3 \\
\hline $88 \mathrm{E}-12.1-07$ & $\mathrm{~F}$ & Mid-old age & E. Chalcolithic & OxA-20597 & 6800 & 36 & -19.32 & 8.96 & 3.4 \\
\hline
\end{tabular}


Figure 2. Suggested routes for the spread of agriculture from the Near East into Europe (from Tringham 2000, after Renfrew 1987).

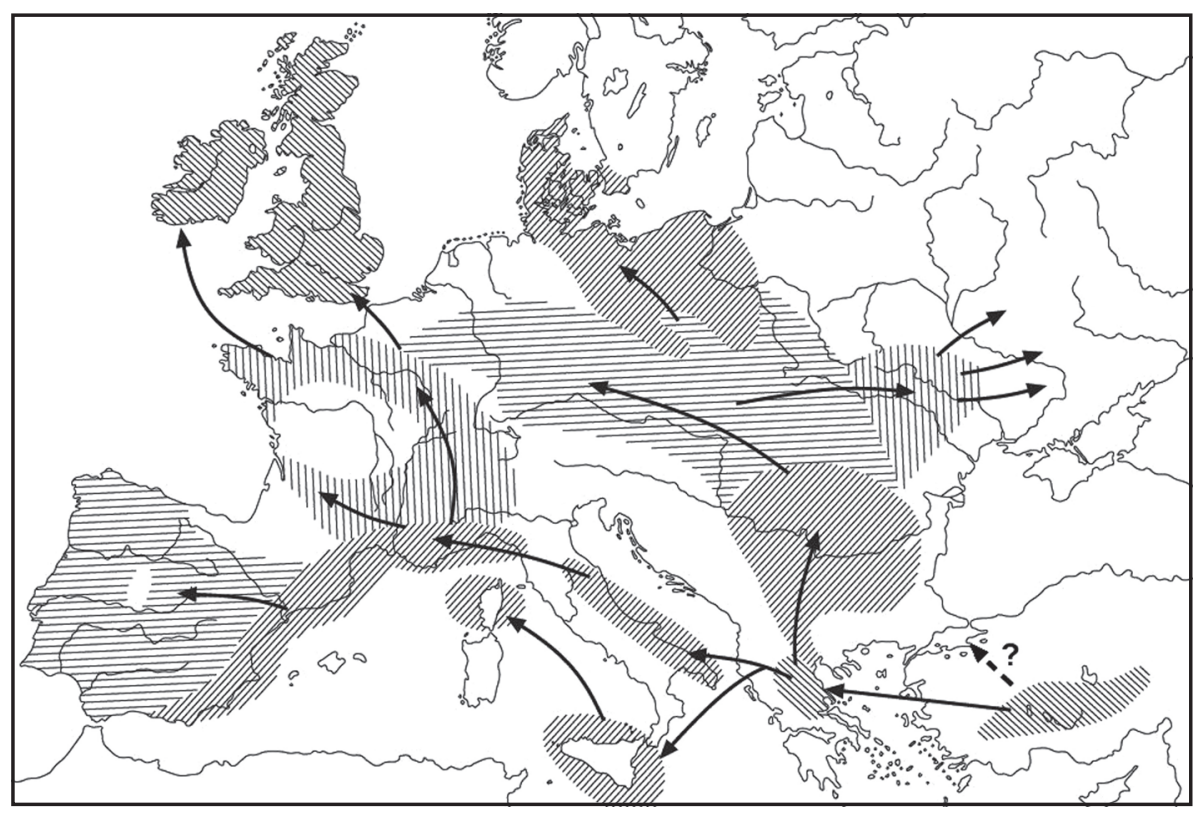

what is an hitherto relatively under-represented region in our investigations of the myriad processes of the dissemination of agriculture from the Near East into south-eastern Europe (although see Özdoğan 2011 for a recent overview).

In general, it is assumed that Neolithisation in the Marmara region occurs through migration, as there is currently a lack of secure evidence for a Mesolithic presence. Indeed, Özdoğan $(2011,419)$ notes that "even in the most intensively surveyed areas of western and northern Anatolia, material indicative of the presence of an Epipalaeolithic/Mesolithic horizon, as is the case in Greece and southern Bulgaria, is restricted to the coastal areas, suggesting that the inner parts might be devoid of population". Again, whilst this situation is perplexing, there are numerous aspects influencing the "visibility" of earlier groups, not least due to factors such as historical perceptions of the region, conceptual biases that have placed an emphasis on the search for the Neolithic and Neolithisation processes, historical issues of accessibility, regional/political and nationalistic biases, and ultimately even the fact that the Neolithisation process "means something different in different parts of the world and in different parts of Europe" (Tringham 2000, 23; Zvelebil, Lillie 2000).

However, even though there has perhaps been a bias in favour of the investigation of early farming sites throughout southeastern Europe and in the central parts of Anatolia, and whilst the early farming settlements of northwestern Anatolia have evidence for fully developed farming economies (e.g. at sites such as Menteşe, Barcın and Ilıpınar), and contemporary sites in coastal locations, such as Fikirtepe, Pendik and Yenikap1, and sites such as Aktoprakl1k, appear to provide evidence for adaptation to the farming way of life, these sites have yet to be studied from the additional perspective of stable isotopic studies of human diet alongside palaeopathological investigations. Therefore, whilst the available archaeological data suggests variability in subsistence strategies and settlement patterning, perhaps suggesting that the "simple" scenario of immigration of farming populations is not pertinent for this region, in reality there may in fact be a "hybridisation" of migration and indigenous adaptation as farming is introduced; although this hypothesis remains to be tested by further investigation through a regional survey alongside the aforementioned direct analysis of the skeletal remains from Neolithic sites in the region.

By using palaeoanthropology alongside stable isotope analysis of human and faunal skeletal remains, the current study aims to test whether it is possible to determine if the Neolithic population at one site, Aktoprakl1k, exploited a wide range of wild resources (e.g. freshwater and terrestrial resources), as were available at the local and regional level, or whether, as in adjacent regions (e.g. Papathanasiou 2003), the population at Aktopraklik was already focussing their subsistence activities on a limited range of domesticated plant and animal resources as might be anticipeted if they were incoming farmers in this region.

\section{The Study Site}

The site of Aktopraklik was originally discovered in 2002 during archaeological survey in advance of the development of an industrial area (Karul 2007; Karul; Avc1 2010; 2011). Aktopraklik is located ca. $25 \mathrm{~km}$ to the west of Bursa (and $c a .100 \mathrm{~km}$ to the south of Istanbul) on a terrace situated on the eastern edge of Lake Ulubat (Figure 1). As such, this site is positioned at a significant point in relation to cultural development and the dissemination of agriculture from East to West (Özdoğan 1997; 2007); with the caveat (as noted by Özdoğan 2007, 19) that "the western border of the eastern Neolithic is not a static one, but one that moves over time from central Anatolia to the Balkans".

The settlement and cemetery sites at Aktopraklık were positioned between two river beds, and on a ridge to the north 


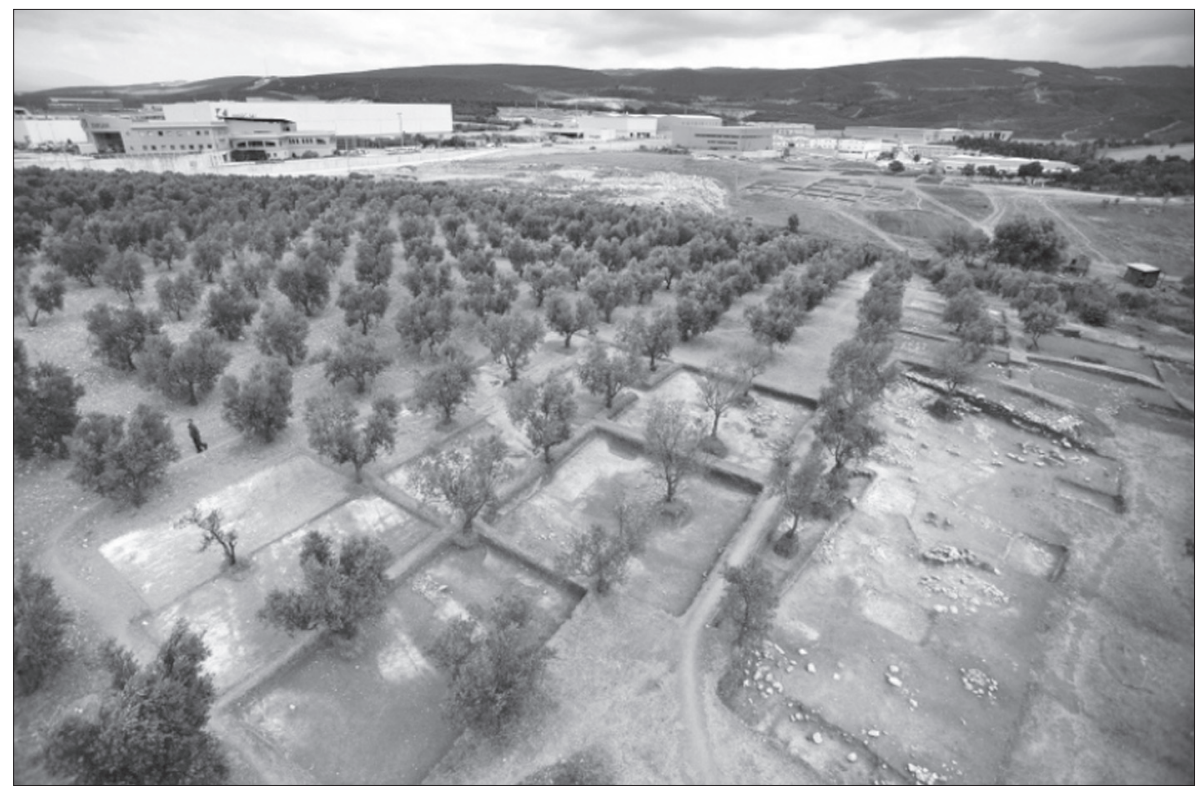

Figure 3. View over the area of the Aktoprakil C excavations (from Karul, A. 2011).

of one of these river beds. The settlement has been impacted upon by olive trees, which grow on the site at the present, and by a Byzantine site, the ruins of which were recorded to a maximum depth of $c a$. $1 \mathrm{~m}$, penetrating into the Neolithic levels at this location. In addition to the above impacts, during the Chalcolithic period part of the site (Aktopraklik $\mathrm{C}$ - Figure 3) was used as a cemetery after the settlement had been abandoned and relocated. The location of the site, close to an extinct river course and an extant spring, and on a level raised area on the shores of Lake Ulubat, would suggest that the occupants of the Neolithic and Chalcolithic sites were ideally situated to exploit both fresh and salt water resources and the adjacent forest zone (Karul, Avc1 2011, 2).

The excavations at Aktopraklik (area C) have shown that the site comprised two phases of Neolithic occupation, the earliest of which is badly truncated by the overlying Byzantine activity, but this earlier phase does have two small structures $c a$. 1 and $1.5 \mathrm{~m}$ in diameter respectively in evidence. The subsequent phase of occupation is better attested, with evidence for paved courtyards and five structures with $c a$. 3-6 m diameter huts, three of which had stone wall bases and concave floors. One of the better preserved floors sloped down to a maximum of ca. $0.4 \mathrm{~m}$ depth in the centre, being excavated into the bedrock, whilst another structure which was also $0.4 \mathrm{~m}$ deep at the centre, had been paved with small stones. Three of the structures had dome shaped ovens located close to the walls; these had a diameter of $c a .0 .6 \mathrm{~m}$. Within the settlement area a number of refuse pits, $c a .1 .5 \mathrm{~m}$ in diameter were excavated. These pits contained large numbers of cattle, ovicaprine and some deer bone and were capped with stones once they were full (Karul, Avc1 2011, 3).

The available archaeological evidence suggests that the Fikirtepe culture is defined by its round, wattle and daub structures, and a broad resource procurement strategy which placed a reliance on fishing, mollusc collecting and hunting and gathering, along with the exploitation of some domesticated animals and plant cultivation (Özdoğan 2010). Given the range of resources available in the Marmara region, it is perhaps unsurprising that there is some suggestion of variability in the subsistence strategies being exploited during the Neolithic period, but again, limitations exist in that there is currently only indirect evidence for the consumption of wild resources. For instance, the evidence from Ilıpınar (Roodenberg 1999; Özdoğan 1999; Cappers 2008), a site located ca. $60 \mathrm{~km}$ to the north-east of Aktopraklik (Figure 1) indicates that a fully agricultural economy, utilising a wide range of domesticated plant species, and in which sheep, goat and cattle dominate the domesticated faunal species, is being exploited (Buitenhuis 2008). The inhabitants of Ilıpınar consumed a broad spectrum of plant resources including naked and hulled barley, einkorn and emmer wheat, bitter vetch, pea (including grass and chick pea), flax (probably exploited for fibres), faba bean, and lentils, with a gathered component comprising fig, bramble, grape, apple/pear, hazel and pistachio nuts (Cappers 2008). An important observation from the investigations at Ilıpinar is the suggestion that traction animals may have been fed with barley, and also that dung was being used as fuel for the ovens at this location (Cappers 2008, 120).

To date there is relatively little reported evidence for the plant-based subsistence activities at Aktopraklık (Karul, Avc1 2011). The current lack of information in relation to the subsistence activities at Aktopraklık makes the present study of some importance to our understanding of this site in its regional context. The main information for diet comes from the refuse pits (mentioned above) that contained cattle, ovicaprine and deer bones. Analysis of these features is ongoing, but pit $88 \mathrm{E} / 24$ at this site is dominated by cattle bones, with sheep/goat and (very) occasional finds of fallow deer in evidence, and the remains of both subadult and adult animals are represented in the faunal assemblage.

Karul and Avc1 $(2011,3)$ have interpreted these features as representing the collective butchering and consumption 
of animals at regular intervals (feasting events?), alongside daily food consumption activities at the household level. In addition, the association of faunal remains with a number of Neolithic interments in pits, and other areas of the settlement site, has produced evidence for cattle, pig and sheep/goat; primarily in the form of fragmentary material, and there are also similar faunal associations with the Chalcolithic cemetery at Aktopraklık $\mathrm{C}$. While the faunal remains associated with the interments may represent food for the deceased to take into the afterlife, these ritual associations cannot a priori be assumed to equate to everyday food consumption patterns, and further conclusions in relation to the exploitation of animals at Aktopraklik are dependent on future faunal studies.

\section{The Regional Context}

In the past two decades around 26 Neolithic and Chalcolithic sites have been excavated in the Marmara region of Anatolia, with the majority of these being multilayered mound (tell) sites e.g. Ilıpınar and Menteşe, while Aktopraklık is a flat settlement site more typical of European settlement forms (Karul, Avc1 2011, 5). As a result of this recent work, large areas of the Anatolian peninsula are now considered to be an integral part of the primary zone of neolithisation (Özdoğan 2007, 19), and the available evidence suggests that the transmission of farming followed both maritime and inland (Anatolian plateau) routes (ibid).

Özdoğan (2008) identifies an interim zone, wherein the transmission of agriculture (and the agricultural package) from the primary zone of neolithisation does not occur before the end of the seventh millennium BC. This interim zone is defined as covering all of the western parts of Anatolia, the Aegean, the Marmara region and most of the Balkans (ibid. 2008, 143). In effect, this zone would equate to an area wherein selective colonisation is taking place (sensu Zvelebil 1986, 12; Zvelebil, Rowley-Conwy 1984), being dependent on the availability of fertile areas, and with a mixture of direct colonisation and an "availability" phase occurring simultaneously, depending on the nature of the existing populations and the speed with which they are prepared to "participate" in the process of change (Figure 4).

Figure 4. Frontier zones, concentrations of Mesolithic settlement and the earliest Neolithic cultures in southeastern Europe (Sources: Tringham 1971; Müller 1988; Chapman, Müller 1990; Kozlowski, Kozlowski 1986; Özdogan 1983; Budja 1993; Dergachev et al. 1991; from Zvelebil, Lillie 2000, 71).
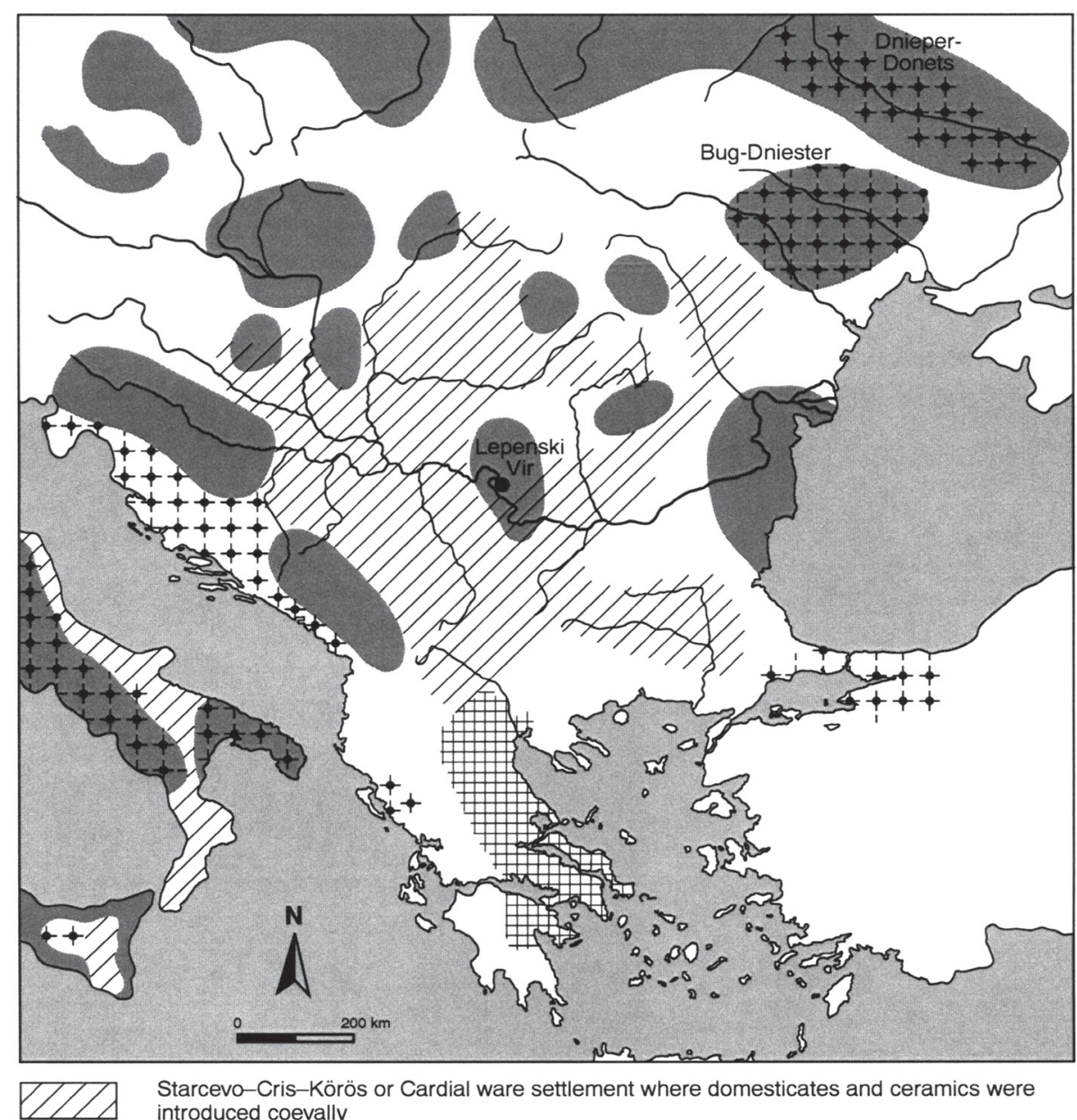

Starcevo-Cris-Körös or Cardial ware settlement where domesticates and ceramics were introduced coevally

Greek Early Neolithic marked by the limited provision of ceramics and by occasional aceramic layers

Areas where pottery was introduced first into forager communities in the "Availability" phase

Areas of concentrated hunter-gatherer settlement 
The perceptional difficulties inherent in evaluating the nature of the process of change in a region with a paucity of evidence for hunter-fisher-forager groups is acknowledged, although the archaeological evidence for a potentially mixed range of subsistence strategies at Neolithic sites must either be considered to equate to indigenous influences, or, as an alternative, we might also perhaps consider the probability that early farmers were not unaware of (or incompetent in) using hunting and foraging as supplementary modes within subsistence strategies. This scenario is especially pertinent where farming is being introduced into an hitherto unexplored region, where some phase of adaptation of farming practices may be necessitated. In our efforts to introduce volition to hunter-gatherers in the process of change there is sometimes a failing on the part of archaeologists in recognising the fact that the first farmers were originally hunter-gatherers; perhaps we should be more open to the notion that as huntergatherers can develop strategies that lead to management and domestication of wild resources, or choose to adopt elements of an existing "package" of resources as they see fit, so too, farmers should be perfectly capable of integrating hunting and foraging as the situation demanded or as needs dictated. In the modern context many farmers are adept hunters, both forms of subsistence are not mutually exclusive whether approached from the perspective of hunter-gatherers or vice versa.

So, despite some limitations in the evidence for indigenous foraging populations, it is appropriate to approach the region of northwestern Turkey in which Aktopraklık is located as a potentially diverse and culturally complex region both in terms of its geography and the nature, origins and development of agriculture, and indeed, in relation to the nature of the adoption and adaptation of the various elements of the agricultural "package" (Greaves 2007). On the basis of the excavations, assessments and fieldwalking at sites such as Fikirtepe, Pendik, Yarımburgaz, Ilıpınar, Menteşe, Barcın, Aktopraklık and Demircihöyük, alongside landscape surveys in the western areas of the plateau, it is now generally accepted that the Fikirtepe culture was much more widespread in the western regions of Anatolia than previously realised. Özdoğan (2008:151) suggests that the origins of this culture may lie in the Central Anatolian plateau, probably in the Lake District region. It is perhaps also worth noting that whilst "the environmental conditions in the western part of the Anatolian peninsula, including the Sea of Marmara", differ from those pertaining further south and east in Anatolia, and that it is these less arid conditions that allow for the transformation of "almost all components of the Neolithic culture" prior to its dissemination into Temperate Europe (Özdoğan 2007, 21), these differing environmental conditions may not immediately be ideally suited to plants and animals that have pre-adapted to the more arid conditions in the south and east of the region.

We feel that, in light of the mosaic nature of the landscape and cultural developments in Anatolia, the inherent difficulties in determining the nature of the subsistence economy are exacerbated in certain locations, such as at
Aktopraklık, where the archaeological record is made even more fragmentary by post-depositional disturbances, e.g. Byzantine settlement and olive groves. In these contexts the application of a multi-disciplinary approach to the available archaeological record, as advocated by Marek Zvelebil during the recent investigations at the LBK farming site of Vedrovice, Moravia, Czech Republic (Lukes, Zvelebil 2004, Lukes et al. 2008, Zvelebil, Pettitt 2008, Lillie 2008, Richards et al. 2008) is warranted. The integration of palaeopathology and stable isotopic studies of diet combine to offer a greater potential for the identification of subsistence practices at sites such as Aktopraklık.

\section{Anthropology \& Archaeology}

To date more than 60 burials have been recovered during systematic excavations at this site, with fragmentary material from 14 individuals having been recovered during test pitting undertaken by the Bursa Museum. A dozen burials were recovered from the settlement area of Aktopraklık B, all dated to the Early Chalcolithic period, while more than two dozen individuals have been recovered from the Chalcolithic cemetery at Aktopraklık $\mathrm{C}$, which covers an area of $c a$. $1400 \mathrm{~m}^{2} .14$ burials were recorded from the Late Neolithic layers of Aktopraklık C, with some of these being placed beneath the floors of the houses. All of the burials from Aktopraklık B and C were placed in a flexed position, with a range of grave goods in association. The majority of the Neolithic burials include monochrome pottery, which is typical for this period, along with bone tools and stone beads of differing form included as accompanying grave goods. The Chalcolithic burials in areas B and C were interred in simple pits, with associated grave goods including limestone beads, bone tools, spatula and spoons made of bone as well as celts, and a number of faunal remains placed in direct association to the internments. Most of the Chalacolithic burials have pottery vessels placed at the feet and heads of the interred individuals. The Neolithic practice of interment within the settlement is abandoned by the Chalcolithic period at Aktopraklık $\mathrm{C}$ as a shift away from "living with the dead" to a concept of a "city of the dead" develops (Karul, Avc1 2011, 5).

Alpaslan Roodenberg (2011a) has reported on 42 burials that were recovered between 2004 and 2009, recording the presence of 37 adults (comprising 15 females/probable females, 15 males/probably males and 7 individuals of indeterminate sex) and 7 infants and juveniles. Preservation varied across the site, with a number of individuals represented by very fragmented remains, and $c a .80 \%$ of the adults being preserved in either a fragmentary or poor condition. All but a few burials were single, and interred in regular pit graves. In addition, however, possible multiple burials (89E-9.1-3) included three individuals and another burial including two individuals (89D-17.1 and 14.1) were located in the same context. All are primary burials, in contrast to the partly contemporary Çatalhöyük site where secondary interment was customary (Andrews et al., 2005: 263). 
Figure 5. Double burial of two, probably middle aged to old adult males at Aktopraklık (Individual 14.1 has his head resting on the feet of individual 17.1)

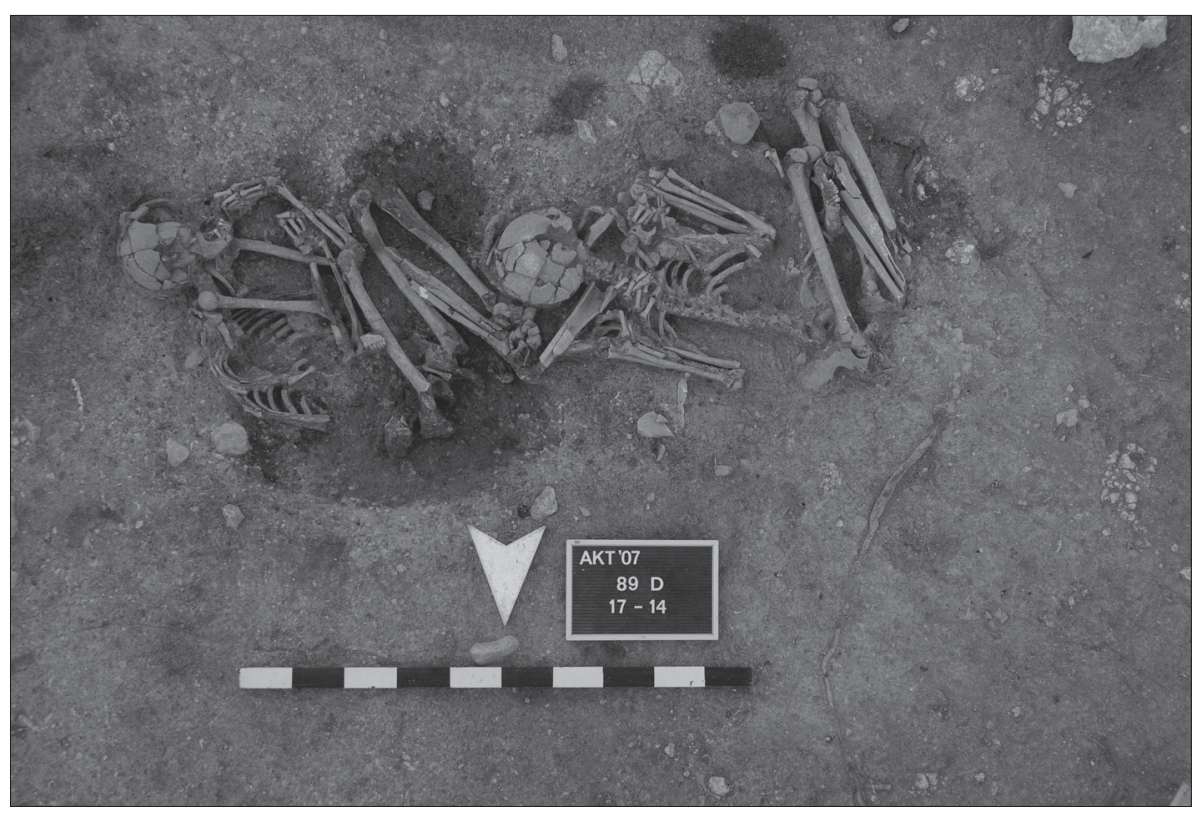

The triple burial at Aktopraklik (89E-9.1-3) appears to have comprised the burial of an adult male (of indeterminate age) and female (aged between 25-35 years of age), with a juvenile (2-4 years of age), the chronology of interment is not established however as it is possible that the interments do not represent a single burial episode. The double burial comprises two, probably middle aged to old adult males. Interestingly the head of individual 14.1 rested on the feet of individual 17.1 (Figure 5).

One particular individual warrants mention at this point, individual $15 \mathrm{G}(82)$, was the best preserved of the skeletal remains at Aktopraklık. This individual was a male, buried in a Chalcolithic grave, who was between 30-35 years of age at death, and who had a muscular build and an estimated height of $168 \mathrm{~cm}$ (Alpaslan-Roodenberg 2011b). This male individual had a microlithic trapeze embedded in the anterior portion of the third lumbar vertebra, a little left of the midline (ibid.). It is apparent that this object represents the tip of an arrow that passed through $c a .15 \mathrm{~mm}$ of soft tissue before making a $12 \mathrm{~mm}$ deep slit in the vertebra. The lack of evidence for healing suggests that the impact damage from the arrow was lethal (Alpaslan-Roodenberg 2011b, 61). According to Alapaslan-Roodenberg, it is probable that this individual was shot from close range, whilst lying on the ground, with the assailant standing above and in front of the prone victim $(2011 \mathrm{~b}, 60)$.

An additional point of interest in the context of individual $15 \mathrm{G}(82)$ is the observation that the flint arrowhead is of a form usually characterised as being of Mesolithic type, it is not an artefact that has been found in Neolithic or later contexts (Alpaslan-Roodenberg 2011b). It is however characteristic of Bulgarian Thrace during the Neolithic and Chalcolithic periods, a region that has common cultural traits with north-west Anatolia during the sixth millennium BC (Roodenberg 2008, 81).
There are a number of important artefact associations and palaeopathological observations that are significant to the current study. Artefact associations include fragments of sheep/goat mandible on the leg bones of both males interred in the double burial (89D-17.1 and 14.1), animal bone fragments were spread at the back of individual 90D-11.1, an aged adult male, and 89D-13.1, a female aged 35-45 years had a fragment of sheep/goat mandible on the lower arm. A number of males and females had ceramic vessels in association, and two interments (89E-17 and 89F-6) have stone axes placed near the head. Both males and females have limestone beads (probably representing necklaces, bracelets or perhaps head dresses), in association.

Significantly, one of the child burials (89E-14.1), an individual aged $4 \mathrm{yrs} \pm 12$ months, had a necklace comprising 49 limestone beads and a pierced seashell in association, whilst individual 13F-7.1, aged 11-14 years, had a pot near the head, and individual 87E-6 (aged 12-14 years) had a small and a larger pot superimposed on each other near the face and hands, and a third pot near the pelvis, along with a marble bracelet around the right upper arm. The association of artefacts with the non-adult burials suggests that these individuals were considered to be members of the community, even before they had been weaned off their mother's milk.

Palaopathological analysis of the dentitions of 38 individuals (33 adults and 5 children) at Aktopraklık has shown that, with the exception of 6 adult individuals that did not have dental remains preserved, all of the remaining individuals analysed exhibited some form of dental pathology. Only one non-adult (13F-7.1) had pathology in evidence in the oral cavity (Alpaslan-Roodenberg 2011a, 29-30); this individual, an adolescent aged between 11-14 years, had calculus deposition and severe alveolar atrophy in evidence. Nearly half of the thirty three adults studied exhibited dental caries, 
often with periapical abscesses, and calculus was recorded on all of the available adult dentitions. Ante-mortem tooth loss was frequent in the population, and heavy tooth wear was recorded for both adults and children, indicating a coarse component in the diets at Aktopraklik. Interestingly, in relation to the adult population, 9 of the 15 Neolithic inhabitants at Aktopraklık exhibit carious lesions (5 females and 4 males), whilst in the Chalcolithic period 5 females and only one male exhibited this pathology. In general, the majority of Neolithic individuals exhibited poor oral health, with carious teeth with periapical abscesses, ante mortem tooth loss and periodontal disease, whilst it is the females in the Chalcolithic period that exhibit the highest levels of dental pathology at a time when male oral health improves considerably. A similar situation in respect of the higher female incidences of dental pathology has been reported at the site of Ilıpınar (Alpaslan-Roodenberg 2008, 47).

Two of the interred individuals (88E-12.1), a female of mid-old age, and (89D-16.1) a female aged 25-35 years, had unusual wear gradients in the anterior dentition. In the case of the female aged 25-35 (89D-12.1), the wear pattern is reported as being the same as is seen in contemporary populations where the teeth are used as a tool in weaving and basketwork (Alpaslan-Roodenberg 2011a, 23). In addition, one male individual aged at between 50-70 years at death, exhibited heavily worn mandibular incisors (the maxillary incisors having been broken post-mortem), that suggest habitual use of the incisors as a tool. Similar grooving on the teeth has been noted at the sites of Ilıpınar and Menteşe, where at the former site most of the females exhibited this pathology (Roodenberg, Alpaslan-Roodenberg 2008, 13).

In general, the heavy incidence of dental disease, especially the presence of caries and calculus, suggests that these populations were consuming a mixed carbohydrate and protein based diet across both periods, with the reduction in the frequency of dental pathology for males in the early Chalcolithic period probably indicating a shift away from cariogenic foodstuffs by males at this time.

\section{Stable Isotope Studies of Diet}

The analysis of $\delta^{13} \mathrm{C}$ and $\delta^{15} \mathrm{~N}$ isotopes can provide an extremely useful addition to studies of prehistoric diet and subsistence as bone isotopic composition is determined by the food that an individual consumes. As noted by Müldner and Richards $(2005,40)$, stable isotope analysis for palaeodietary reconstruction is based on the principle that the isotope values $\left(\delta^{13} \mathrm{C}\right.$ and $\left.\delta^{15} \mathrm{~N}\right)$ of the food consumed by animals and humans are stored in the individual's tissues. A caveat to this general observation is the fact that the isotopic composition of the mineralised tissues of vertebrates has been shown to exhibit variability at the intra-individual level of analysis (e.g. Balasse et al. 1999, 593, and references therein). In general though, the ratios that are derived from stable isotopic analysis provide an indication of the proteins consumed by an individual in the last $c a$. 10 years of their life.
The analysis of the carbon isotope value, $\delta^{13} \mathrm{C}$, from bone collagen provides an indication of the amount of marine protein in the diet, as compared to terrestrial or freshwater protein, and bone collagen analysis also distinguishes between different dietary components such as $\mathrm{C}_{3}$ and $\mathrm{C}_{4}$ photosynthetic plants and the animals that consumed them (Schoeninger, DeNiro 1984; Schwarcz, Schoeninger 1991; Lillie et al. 2003; Richards 2002).

Humans with a diet where all of the protein is derived from marine sources have bone collagen $\delta^{13} \mathrm{C}$ values of approximately $-12.1 \%$ (Chisholm et al. 1982; Richards, Hedges 1999; Schoeninger et al. 1983). In Europe, Holocene human $\delta^{13} \mathrm{C}$ bone collagen values of $c a$. -20 to $-21 \%$ are indicative of terrestrial $\mathrm{C}_{3}$ pathways plants, and the meat or milk of animals consuming these (Richards et al. 2003, 69). Although as noted by Schulting $(2011,19)$ there appears to be a slight shift between north and south Europe, with values in northern Europe being ca. 1-2\% lower than those in southern Europe.

Finally, nitrogen stable isotope ratios $\left(\delta^{15} \mathrm{~N}\right)$ are used to establish the trophic level of an organism in the food web as increases of $c a$. 2-4\%o occur as you move up the food chain (Schoeninger, DeNiro 1984; Mülder, Richards 2005). Although variability occurs throughout Europe, especially in areas such as the Danube and Dnieper river systems where the inclusion of freshwater resources elevates the $\delta^{15} \mathrm{~N}$ ratios, thus necessitating the analysis of faunal/fish remains alongside human remains wherever possible (Lillie et al. 2003; 2011; Lillie, Budd 2011; Schulting 2011).

At Aktopraklik we were able to study 23 of the 60 individuals that have been excavated to date, with the samples comprising 20 adults (10 males, 8 females and 2 indet adults) and 3 children below $c a .12$ years of age). In addition, six faunal samples from cattle, pig and sheep/goat were included in this preliminary analysis in order to facilitate a consideration of trophic level shifts (Figures 6-8).

The data are intriguing as they suggest that the fauna are grazing on a range of plant resources; the Sus sample produced the most negative carbon and lowest nitrogen ratios for the faunal series studied, at $-21.2 \%$ for $\delta^{13} \mathrm{C}$ values and $4 \%$ for $\delta^{15} \mathrm{~N}$, with the cattle ratios being $-18.0 \%$ to $-19.4 \%$ o for $\delta^{13} \mathrm{C}$ and $5.0-8.8 \%$ for $\delta^{15} \mathrm{~N}$. The sheep/goat samples have values of $-19.7 \%$ and $6.6 \%$ and $-20.3 \%$ and $4.8 \%$ for $\mathrm{C}$ and $\mathrm{N}$ respectively. The samples from the humans for the Neolithic period have ratios of $-20.14 \%$ o to $-20.62 \%$ for $\delta^{13} \mathrm{C}$ and $8.37 \%$ to $11.13 \%$ for $\delta^{15} \mathrm{~N}$. Whilst the range for $\delta^{15} \mathrm{~N}$ does extend up to above $11 \%$ o this is not inconsistent with the potential range that is suggested by the isotope ratios for the fauna, and would be consistent with a $\mathrm{C}_{3}$ based diet, comprising the plants themselves and the animals that browsed upon them.

For the Chalcolithic period the overall ranges are $-20.7 \%$ to $-19.39 \%$ for $\delta^{13} \mathrm{C}$, and $8.71 \%$ to $12.83 \%$ or $\delta^{15} \mathrm{~N}$. These ranges would initially indicate the consumption of dietary protein over two trophic levels. However, the highest $\delta^{15} \mathrm{~N}$ value for the Chalcolithic individuals, at $12.83 \%$, belongs to a child of pre-weaning age (burial 89E-14.1-07). The 
Figure 6. Mean values of Neolithic males and females.

Figure 7. Mean values of Chalcolithic males and females.

Figure 8. Mean values of Neolithic and Chalcolithic adults (combined male/female values).
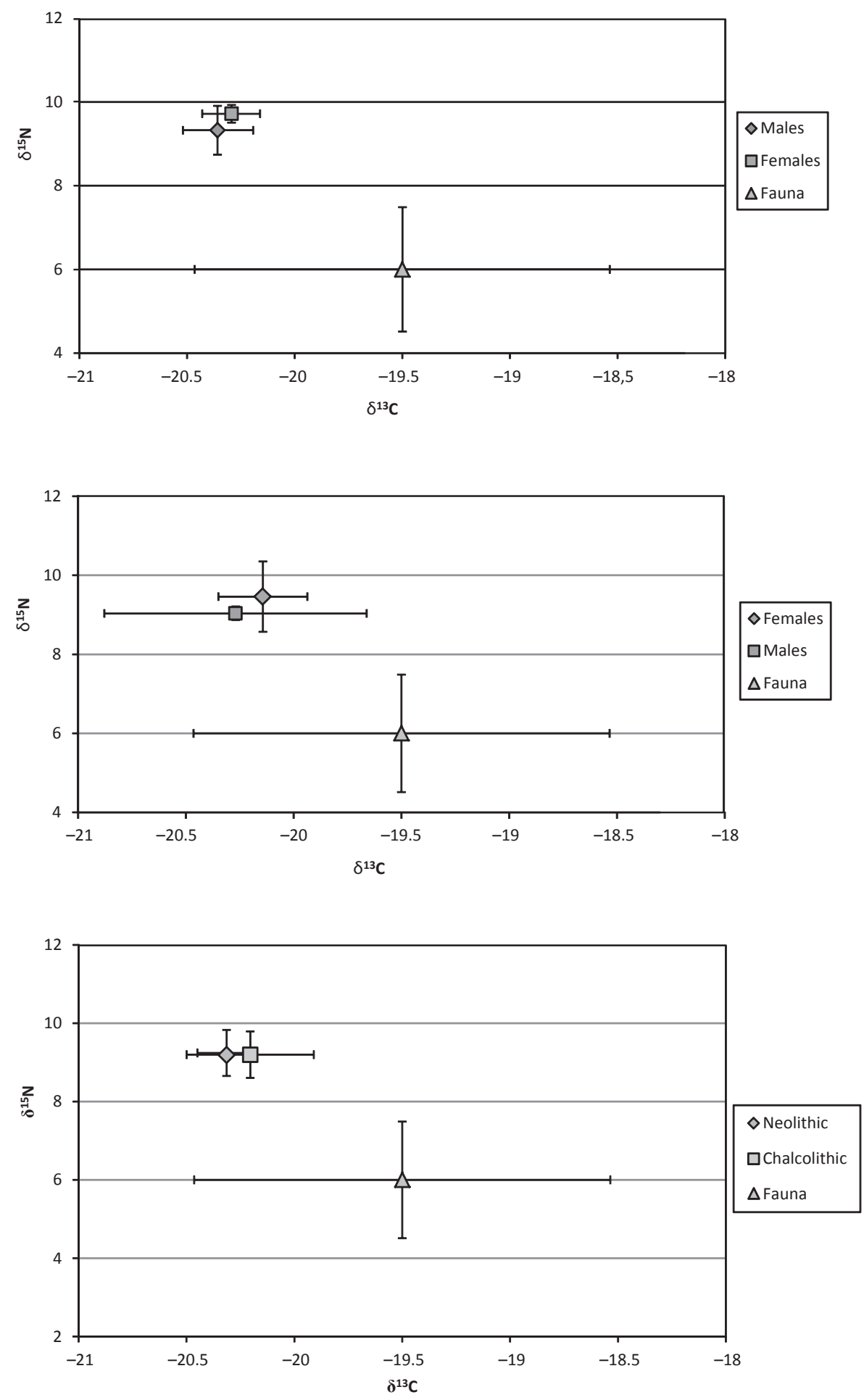

revised $\delta^{15} \mathrm{~N}$ range with this sample removed is $8.71 \%$ to $10.49 \%$ o $(1.78 \%$ o), which is within one trophic level and would again suggest a reliance upon $\mathrm{C}_{3}$ plant species and herbivores. The data for the Chalcolithic period are of some interest when we compare the human against the faunal values as the faunal material from the Chalcolithic period is more enriched in $\delta^{13} \mathrm{C}$ than that of the human samples (ca. 1-2\%o) and the difference in $\delta^{13} \mathrm{C}$ values between the humans and fauna is statistically significant (at $\mathrm{p}=0.01667$ ).
This suggests that it is perhaps unlikely that the Chalcolithic humans were consuming the same plant species as the Chalcolithic fauna, or indeed the fauna itself, and that there is a shift in diet across the Neolithic to Chalcolithic period at this location. These preliminary observations are intriguing, and clearly need to be investigated in much more detail if we are to develop an accurate and more nuanced understanding of the development of farming in NW Anatolia. 
In general, the results of this initial study have shown that the data is indicative of overall homogeneity in subsistence strategies for this farming population. The isotope values indicate a focus on $\mathrm{C}_{3}$ terrestrial resources at Aktopraklık, despite the close proximity of both freshwater and marine environments from where alternative resources could have been procured, even though the nature of these exploitation strategies may be exhibiting some evidence for a shift in the emphasis that is placed on certain plant species across the Neolithic to Chalcolithic periods. This scenario has some similarities to that discussed for the northern Balkans by Tringham (2000:25) wherein the immigrant population were "under-utilizing the riches of their local micro- and macroenvironments in terms of food and other resources, either through ignorance or through a resistance to venturing far in space or concept into the unknown".

\section{Discussion}

The newly developing research agenda into human populations in the Marmara region of NW Anatolia is a research area that would have, no doubt, been of considerable interest to Marek Zvelebil. It would have been fruitful to be able to sit and discuss aspects of the transition and the changing appearance of farming cultures in this region, and to consider how the evidence might be interpreted. There is little doubt that much more information will be forthcoming from an approach that integrates dating, isotope studies, palaeoanthropology, archaeology and ancient DNA analysis on the populations of this region. The preliminary results obtained from a combination of four of these areas of investigation are already suggesting that there are subtle variations in evidence between the later Neolithic and Chalcolithic periods. A finer resolution to the data will be afforded by a more detailed study of the dating of the burials and discrete contexts from the settlement sites in the region, and from an approach that integrates sampling for isotopic studies and DNA analysis from the outset of an excavation programme.

As with the LBK culture ( $c f$. Lukes, Zvelebil 2004), the Fikirtepe culture is not a homogenous entity, it is characterised by variations in settlement form, material culture inventories and as the above discussions indicate, in terms of subsistence strategies. Elsewhere this variability has been seen to indicate continuity and the integration of indigenous hunterforager material culture and world views as food-production economies spread across Europe (Zvelebil, Pettitt 2008). In the current study, the presence of wild fauna in discrete depositional contexts at Aktopraklık appears to suggest that the subsistence strategies at this site would contrast to those in evidence at sites such as Ilıpınar, where a fully developed farming economy with an emphasis on a broad spectrum of plant resources and where sheep, goat and cattle dominate the domesticated faunal species is being exploited.

However, whilst Karul and Avc1 $(2011,3)$ have interpreted the pits containing fauna from cattle, sheep/goat and deer as representing the collective butchering and consumption of animals at regular intervals, alongside daily food consumption activities at the household level, the stable isotope and anthropological data is perhaps providing a more nuanced scenario for the subsistence activities at this location. It is entirely feasible to suggest that feasting activities may be attested by these deposits, and the stable isotope data does not conflict with the idea that the later Neolithic population interred at Aktopraklik exploited a combination of $\mathrm{C}_{3}$ plant resources and the animals that browsed upon them. Furthermore, the anthropological data highlights a combination of carbohydrate and protein consumption through the expression of dental caries and calculus, and the articulation of faunal remains in association with the Neolithic burials, e.g. with fragments of sheep/goat mandible on the leg bones of both males interred in the double burial (89D-17.1 and 14.1), animal bone fragments spread at the back of individual 90D-11.1, an aged adult male, and a fragment of sheep/goat mandible being placed on the lower arm of a female (89D-13.1) who was aged 35-45 years when she died, all attest to the significance of animals to this population. The individuals who were burying their dead in the later Neolithic period certainly appeared to consider the inclusion of elements of sheep/goat (and probably other animals) as important votive offerings in these contexts.

Both the stable isotope and anthropological data adds greater resolution to our study in that these techniques are indicating that a shift in the nature of subsistence strategies is occurring across the Neolithic to Chalcolithic transition. The anthropological evidence is indicating that in the Chalcolithic period females have higher levels of dental pathology than males, presumably due to a greater emphasis on the consumption of carbohydrates, and also that male oral health actually improves considerably. A similar situation in respect of the higher female incidences of dental pathology has been reported at the site of Ilipınar (Alpaslan-Roodenberg 2008, 47). Similarly, the stable isotope data appears to indicate a shift in the nature of food procurement patterns, with an emphasis being placed on $\mathrm{C}_{3}$ plants as opposed to domesticated fauna, and the data also suggest that it is unlikely that the humans were consuming the same plant species as the Chalcolithic fauna, or indeed the fauna itself. This observation is of considerable interest and could conceivably be highlighting a very significant shift in the nature of the farming economies in this region, a shift that would presumably coincide with a reorientation of the materiality of life in the daily cycle of practice and the negotiation of identity in this population. Following the theoretical underpinnings of the work undertaken by Marek Zvelebil at the site of Vedrovice in the Czech Republic, we hope that the current study has laid the foundations for a research agenda that will endeavour to further develop personal biographies and establish the communal identity of the population at Aktopraklık. The intention is that this agenda will ultimately be derived from the application of integrated bio-archaeological analyses of human and material remains from Neolithic and Chalcolithic horizons at this site. 
In endeavouring to generate information aimed at ultimately elucidating personal biographies, through a combination of bioarchaeology, AMS dating and isotopic studies, we hope to be able to identify those individuals that were either indigenous to the region, or who had migrated into the region, and also which individuals might be considered to own the fundamental knowledge essential for the development of food production strategies ( $c f$. Lukes, Zvelebil 2008). In light of these aspirations, this paper is dedicated to Marek Zvelebil's memory in the hope that the considerable potential that an hitherto understudied region has, in terms of producing significant insights into the life histories of human groups as agriculture developed in a region that is still sometimes viewed as peripheral to both central and southeastern Anatolia and also to southeastern Europe, will eventually provide greater insights into the transmission of agriculture from the Near East into Europe.

\section{Acknowledgements}

This paper is dedicated to the memory of Professor Marek Zvelebil, but as the title might suggest, this paper is also aimed at paying our respects to a number of other significant people who are no longer with us, and whose knowledge, advice, mentoring and friendship are sorely missed. In addition to the loss of Marek Zvelebil, the lead author would also like to make mention of a number of other researchers in the fields of Palaeolithic, Mesolithic and Neolithic archaeology who have influenced his work in various ways, and who are no longer with us. In no particular order these are; Professor Vladimir Timofeev, Professor Dmitri Telegin, Dr Roger Jacobi, Dr Ken Jacobs and Professor Pavel Dolukhanov. With the exception of Roger Jacobi who was my lecturer whilst an undergraduate at Nottingham University, all of these colleagues were introduced to me (Lillie) through Marek Zvelebil due to his extensive contacts and wide ranging network of friendships built up during his decades of research in Central and Eastern Europe. During the last few years of Marek's life I (Lillie) had begun to work more closely with Marek. We were discussing a number of projects at the time of his death, and we had begun to develop a research agenda for investigations at Lake Švarcenberk in the Czech Republic (Pokorný et al. 2010).

\section{References}

ALPASLAN-ROODENBERG, S. 2008: The Neolithic cemetery - the anthropological view. In Roodenberg, J. Alpaslan-Roodenberg, S. (Eds.): Life and Death in a Prehistoric Settlement in North West Anatolia: The Ilipinar excavations, Vol. III. PIHANS 110, Leiden, 35-68.

ALPASLAN-ROODENBERG, S. 2011a: A Preliminary Study of the Burials from Late Neolithic-Early Chalcolithic Aktopraklık, Anatolica $37,17-43$.

ALPASLAN-ROODENBERG, S. 2011b: Homicide at Aktopraklık, A Prehistoric village in Turkey, Near Eastern Archaeology 74(1), 60-61.

ANDREWS, P., MOLLESON, T., BOZ, B 2005: The Human Burials at Çatalhöyük. In: Hodder, I. (Ed.): Inhabiting Çatalhöyük: reports from the 1995-1999 seasons. McDonald Institute Monographs and British Institute of Archaeology at Ankara, Cambridge, 261-78.

BALASSE, M. BOCHERONS, H., Mariotti, A. 1999: Intra-bone variability of collagen and apatite isotopic composition used as evidence of a change of diet. Journal of Archaeological Science 26, 593-598.

BUITENHUIS, H. 2008: Faunal remains from the Late Neolithic and Early Chalcolithic levels. In Roodenberg, J., Alpaslan Roodenberg, S., (Eds.): Life and death in a prehistoric Settlement in Northwest Anatolia: The Ilipınar excavations, Volume III (with contributions on Hacilartepe and Menteşe). Nederlands Instituut voor het Nabije Oosten (Netherlands institute for the Near East), Leiden, 205-226.

BUDJA, M. 1993: Neolitizacija Evrope: Slovenska Perspectiva. (The neolithization of Europe. Slovenian Perspective), Porocilo o rziskovanju paleolitika, neolitika in eneolitika v Slovejini 21, 163-93.

CAPPERS, R. 2008: Plant remains from the Late Neolithic and Early Chalcolithic levels. In Roodenberg, J., Alpaslan Roodenberg, S. (Eds.): Life and death in a prehistoric Settlement in Northwest Analtolia The Ilipınar excavations, Volume III (with contributions on Hacilartepe and Menteşe). Nederlands Instituut voor het Nabije Oosten (Netherlands institute for the Near East), Leiden, 117-48.

CHAPMAN, J., MULLER, J. 1990: Early farmers in the Mediterranean basin: the Dalmatian evidence, Antiquity 64, 127-34.

CHISHOLM, B. S., NELSON, D. E., SCHWARCZ, H. P. 1982: Stable carbon ratios as a measure of marine versus terrestrial protein in ancient diets, Science 216, 1131-1132.

DERGACHEV, V., SHERRATT, A., LARINA, O. 1991: Recent results of Neolithic research in Moldavia, Oxford Journal of Archaeology 10, $1-16$.

GREAVES, A. M. 2007: Trans-Anatolia: Examining Turkey as a bridge between East and West, Anatolian Studies 57, 1-15.

KARUL, N. 2007: Aktopraklık 2004-2006 Yili Çalişmalari genel Bir Değerlendirme, Anaştirma Sonuçlari Tpolantisi 25.1, 65-78.

KARUL, N. Avc1, M. B. 2010: The First Farmers of Mamara. İlgi 117, Sevgi Baş (Eds.). Istanbul. 34-39.

KARUL, N. Avc1, M.B. 2011: Neolithic Communities in the Eastern Marmara Region: Aktopraklık C, Anatolica 37, 1-14.

KOZLOWSKI, J., KOZLOWSKI, S. 1986: Foragers of Central Europe and their acculturation. In Zvelebil, M. (Ed.): Hunters in Transition. Cambridge University Press, Cambridge, 95-109.

LILLIE, M. C. 2008: Vedrovice: demography and palaeopathology in an early farming population, Anthropologie XLVI (1-2), 135-152.

LILLIE, M.C. BUDD, C. 2011: The Mesolithic-Neolithic Transition in Eastern Europe: Integrating Stable Isotope Studies of Diet with Palaeopathology to Identify Subsistence Strategies and Economy. In: Pinhasi, R., Stock, J. T. (Eds.): Human Bioarchaeology of the Transition to Agriculture. John Wiley \& sons Ltd., Chichester, 43-62.

LILLIE, M. C., RICHARDS, M. P., JACOBS, K. 2003: Stable Isotope Analysis of Twenty-one Individuals from the Epipalaeolithic Cemetery of Vasilyevka III, Dnieper Rapids region, Ukraine, Journal of Archaeological Science 30, 743-52.

LILLIE, M. C, BUDD, C., POTEKHINA, I. D. 2011: Stable isotope analysis of prehistoric populations from the cemeteries of the Middle and Lower Dnieper Basin, Ukraine, Journal of Archaeological Science 38(1), 57-68.

LUKES, A., ZVELEBIL, M. (Eds.) 2004: LBK Dialogues: Studies in the Formation of the Linear Pottery Culture. British Archaeological Reports International Series 1304. Archaeopress, Oxford.

LUKES, A., ZVELEBIL, M., PETTITT, P. 2008: Biological and cultural identity of the first farmers: Introduction to the Vedrovice Bioarchaeology Project, Anthropologie XLVI (1-2), 117-124.

MÜLDNER, G., RICHARDS, M. P. 2005: Fast or feast: reconstructing diet in later medieval England by stable isotope analysis, Journal of Archaeological Science 32, 39-48.

MULLER, J. 1988: Cultural definition of the Early Neolithic and its interaction in the eastern Adriatic, Berytus 36, 101-25.

ÖZDOĞAN, M. 1983: Pendik: a Neolithic site of Fikirtepe culture in the Marmara region. In Boehmer, R. M., Hauptmann, H. (Eds.): Beitrage zur Altertumskunde Kleinasiens: Festschrift fur Kurt Bittel. Karl Wachholy Verlag, Mainz, 401-411.

ÖZDOĞAN, M. 1997: Anatolia from the Last Glacial Maximum to the Holocene Climatic Optimum: cultural formations and the impact of the environmental setting, Paléorient 23(2), 25-38. 
ÖZDOĞAN, M. 2007: Amidst Mesopotamia-centric and Euro-centri approaches: the changing role of the Anatolian peninsula between the East and the West, Anatolian Studies 57, 17-24.

ÖZDOĞAN, M. 2008: An alternative approach in tracing changes in demographic composition: the westward expansion of the Neolithic way of life. In Bocquet-Appel, J. Bar-Yosef, O. (Eds): The Neolithic demographic transition and its consequences. Springer, Heidelberg, 139-178.

ÖZDOĞAN, M. 2010: Westward expansion of the Neolithic way of life: Sorting the Neolithic Package into distinct packages. In: Matthiae, P., Pinnock, F., Nigro, L., Marchetti, N. (Eds.): Proceedings of the $6^{\text {th }}$ International Congress on the Archaeology of the Ancient Near East. Volume 1 - Near Eastern Archaeology in the Past, Present and Future. Heritage and Identity. Harrassowitz Verlag, Wiesbaden, 883-97.

ÖZDOĞAN, M. 2011: Archaeological Evidence on the Westward Expansion of Farming Communities from Eastern Anatolia to the Aegean and the Balkans, Current Anthropology 52 (S4), 415-30.

PAPATHANASOIU, A. 2003: Stable Isotope Analysis in Neolithic Greece and possible Implications on Human Health, International Journal of Osteoarchaeology 13, 314-24.

PERLÈS, C. 2003: An alternative (and old fashioned) view of Neolithisation in Greece. In Budja, M. (ed.): $10^{\text {th }}$ Neolithic Studies. Documenta Prehistorica XXX, 99-113.

PERLÈS, C. 2004: Les industries lithiques taille'es de Franchthi (Argolide, Grèce). Tome III: Du Néolithique ancien au Néolithique final. Excavations at Franchthi Cave, Greece. Fasc. 13. Indiana University Press, Bloomington - Indianapolis.

PERLES, C. 2005: From the Neolithic to Greece: Let's reverse the process. Cultural elements that didn't transfer. In Lichter, C. (Ed.): How did farming reach Europe? Anatolian-European relations from the second half of the $7^{\text {th }}$ through to the first half of the $6^{\text {th }}$ millennium cal BC. BYZAS 2, 275-290.

PERLÈS, C., TAKAOĞLU, T., GRATUSE, B. 2011: Melian obsidian in NW Turkey: Evidence for early Neolithic trade, Journal of Field Archaeology 36(1), 42-49.

POKORNÝ, P., ŠÍDA, P., CHVOJKA, O., ŽÁČKOVÁ, P., KUNES̆, P., SVĚTLÍK, I., VESELÝ, J. 2010: Palaeoenvironmental research of the Schwarzenberg Lake, southern Bohemia, and exploratory excavations of this key Mesolithic archaeological area, Památky archeologické CI, $5-48$.

RENFREW, A. C. 1987: Archaeology and Language: The Puzzle of IndoEuropean Origins. Cape, London.

RICHARDS, M. P. 2002: A brief review of the archaeological evidence for Palaeolithic and Neolithic subsistence, European Journal of Clinical Nutrition 56(12), 1270-1278.

RICHARDS, M. P., HEDGES, R. E. M. 1999: Stable isotope evidence for similarities in the types of marine foods used by Late Mesolithic humans at sites along the Atlantic coast of Europe, Journal of Archaeological Science 26, 717-722.

RICHARDS, M. P., PEARSON, J. A., MOLLESON, T. I., RUSSELL, N., MARTIN, L. 2003: Stable isotope evidence of diet at Neolithic Çatalhöyük, Turkey, Journal of Archaeological Science 30, 67-76.
RICHARDS, M. P., MONTGOMERY, J., NEHLICH, O., GRIMES, V. 2008 : Isotopic analysis of humans and animals from Vedrovice, Anthropologie XLVI(1-2), 185-194.

ROODENBERG, J. 1999: Ilıpınar: An early farming village in the İznik Lake Basin. In: Özdoğan, M., Başgelen, N. (Eds.): Neolithic in Turkey: Cradle of Civilisation. Arkeoloji ve Sanat Yayinlari, Istanbul, 193-202.

ROODENBERG, J. 2008: The inhabitants. In Roodenberg, J., AlpaslanRoodenberg, S. (Eds.): The Ilipinar excavations, Vol. 3 of Life in a Prehistoric Settlement in North West Anatolia (with contributions on Hacilartepe and Menteşe). Nederlands Instituut voor Het Nabije Oosten, Leiden, 69-91.

ROODENBERG, J., ALPASLAN-ROODENBERG, S. 2008: Ilipinat and Menteşe: early settlement in the eastern Marmara region. In: Bailey, D., Whittle, A., Hoffman, D. (Eds.): Living Well Together? Settlement and Materiality in the Neolithic of South-East and Central Europe. Oxbow Books, Oxford, 8-16.

SCHOENINGER, M., DE NIRO, M. 1984: Nitrogen and carbon isotopic composition of bone collagen from marine and terrestrial animals, Geochimica et Cosmochimica Acta 48, 625-639.

SCHOENINGER, M., DE NIRO, M., TAUBER, H. 1983: Stable nitrogen isotope ratios of bone collagen reflect marine and terrestrial components of prehistoric human diet, Science 220, 1381-1383.

SCHULTING, R. 2011: Mesolithic-Neolithic Transitions: An isotopic tour through Europe. In: Pinhasi, R., Stock, J. T. (Eds.): Human Bioarchaeology of the Transition to Agriculture. John Wiley \& sons Ltd, Chichester, 17-41.

SCHWARCZ, H. P., SCHOENINGER, M. 1991: Stable isotope analysis in human nutritionalecology, Yearbook of Physical Anthropology 34, 283-321.

TRINGHAM, R. 1971: Hunters, Fishers and Farmers of Eastern Europe. Hutchinson, London.

TRINGHAM, R. 2000: Southeastern Europe in the transition to agriculture in Europe: bridge, buffer, or mosaic. In: Price, T. D. (Ed.): Europe's First Farmers. Cambridge University Press, Cambridge, 19-56.

ZVELEBIL, M., 1986: Mesolithic Prelude and Neolithic Revolution. In: Zvelebil, M. (Ed.): Hunters in transition: Mesolithic societies of temperate Eurasia and their transition to farming. University Press, Cambridge, 5-15.

ZVELEBIL, M., ROWLEY-CONWY, P. 1984: Transition to farming in Northern Europe: a hunter-gatherer perspective, Norwegian Archaeological Review 17 (2), 104-28.

ZVELEBIL, M., LILLIE, M. C. 2000: Transition to agriculture in Eastern Europe. In: Price, T. D. (Ed.): Europe's First Farmers. Cambridge University Press, Cambridge, 57-92.

ZVELEBIL, M., PETTIT, P. 2008: Human condition, life, and death at an early Neolithic settlement: bioarchaeological analyses of the Vedrovice cemetery and their biosocial implications for the spread of agriculture in Central Europe, Anthropologie (Brno) XLVI (2-3), 195-218. 